\title{
Estimating the incidence rate of hepatitis B and C in East Azerbaijan, Islamic Republic of Iran
}

Mohammad Hossein Somi, ${ }^{1}$ Simin Khayatzadeh, ${ }^{2}$ Mohammad Nalbandy, ${ }^{2}$ Shahnaz Naghashi ${ }^{1}$ and Zeinab Nikniaz ${ }^{1}$

${ }^{1}$ Liver and Gastrointestinal Diseases Research Center, Tabriz University of Medical Sciences, Tabriz, Islamic Republic of Iran. ${ }^{2}$ East Azarbaijan Provincial Health Center, Tabriz University of Medical Sciences, Tabriz, Islamic Republic of Iran. (Correspondence to: Zeinab Nikniaz: znikniaz@hotmail.com).

\begin{abstract}
Background: The World Health Organization (WHO) has aimed for a $30 \%$ reduction in hepatitis B (HBV) and hepatitis C (HCV) incidence by 2020. To achieve this goal, it is important to have updated information about trends in the hepatitis incidence rate. However, there is a lack of up-to-date data from East Azerbaijan province in the Islamic Republic of Iran.

Aims: This study aimed to estimate the HBV and HCV incidence rate from 2011 to 2016 in East Azerbaijan, Islamic Republic of Iran.

Methods: Hepatitis data and population data were obtained respectively from the national notifiable disease surveillance system and the national Iranian census for 2016. For quantifying the rate of changes in incidence rate from baseline, the average annual rate of reduction (AARR) was calculated. For this, the linear regression model was used for estimating the beta coefficient. SPSS V25 was used for statistical analysis.
\end{abstract}

Results: Over the 6-year period, 3119 hepatitis cases in East Azerbaijan province were reported, of which 94.7\% were hepatitis B. The majority of the affected individuals were $25-44$ years old. HBV incidence was reduced by $12.71 \%$ annually between 2011 and 2016. However, the number of HCV patients increased during 2014-2016, and HCV incidence rate increased insignificantly $(\beta=0.109, P=0.39)$.

Conclusion: There is a significant downward trend of HBV in East Azerbaijan due to mass vaccination programmes. In the case of HCV, when considering the availability of effective treatment regimens in addition to education and prevention programmes, policy-makers should focus on HCV screening and diagnosis, especially in the 25-44 age group.

Keywords: Hepatitis B, Hepatitis C, incidence, infection, Iran

Citation: Somi MH; Khayatzadeh S; Nalbandy M; Naghashi S; Nikniaz Z. Estimating the incidence rate of hepatitis B and C in East Azerbaijan, Islamic Republic of Iran. East Mediterr Health J. 2020;26(7):803-809. https://doi.org/10.26719/emhj.19.077

Received: 31/10/18; accepted: 24/04/19

Copyright (๑) World Health Organization (WHO) 2020. Open Access. Some rights reserved. This work is available under the CC BY-NC-SA 3.0 IGO

license (https://creativecommons.org/licenses/by-nc-sa/3.o/igo)

\section{Introduction}

Viral hepatitis is a public health problem worldwide (1). According to the World Health Organization (WHO), in 2015 about 325 million people worldwide were affected by acute viral hepatitis, from which 275 million cases were related to chronic hepatitis B (HBV) and 71 million cases were related to hepatitis $\mathrm{C}(\mathrm{HCV})(2,3)$. Considering the high burden of hepatitis, WHO has aimed for a $30 \%$ reduction in the incidence of HBV and HCV by 2020 and a $90 \%$ reduction by 2030 (3).

The Eastern Mediterranean Region (EMR) countries have more than 15 million affected people and had the highest prevalence of HCV infection (4). Moreover, in this Region 21 million people had HBV (4). However, the Islamic Republic of Iran has a relatively low endemicity (5).

The prevalence of HBV varied across the Iranian provinces; the highest prevalence was reported in Golestan province $(6.1 \%, 95 \%$ CI: $3.5-8.7 \%)$ (6) and the lowest prevalence was reported in Kermanshah (0.7\%, $95 \%$ CI: 0.4-1.1\%) (6). According to a recent systematic review, the pooled estimated prevalence of $\mathrm{HBV}$ infection was $2.2 \%$ in the general Iranian population from 1990 to 2016 (6). By initiating HBV vaccination programmes from 1993 and blood donor screening programmes from 1996, the improvement in incidence and prevalence rate of viral hepatitis has been expected. There are limited studies in the Islamic Republic of Iran that assess the HBV and HCV incidence trend. In a study in Ilam, Khazaei et al. reported the incidence of HBV and HCV during 2008-2013 and showed an increasing trend in HBV and HCV incidence (7). However, in a study in Hamadan during 2004-2009, a decreasing trend of HBV and HCV was reported (8). In East Azerbaijan, one of the most populous Iranian provinces, the prevalence of $\mathrm{HBV}$ and $\mathrm{HCV}$ was reported to be $1.2 \%$ in 2000 (9). However, no updated report about its prevalence or incidence is available.

Considering the importance of having updated information about the prevalence and incidence of hepatitis for the planning of prevention and treatments programmes, and the lack of studies in this regard in East Azerbaijan, this study was conducted with the aim of evaluating the trend of incidence rate of HBV and HCV during 2011-2016 in East Azerbaijan, Islamic Republic of Iran.

\section{Methods}

The data for this retrospective cohort study were obtained from the national notifiable disease surveillance system in East Azarbaijan province, which is the northwestern 
province in the Islamic Republic of Iran, and consists of 19 counties with a population of 3.909 million and borders the Republic of Azerbaijan and Armenia.

According to hepatitis management guidelines, monthly reporting of hepatitis cases (positive for $\mathrm{HBsAg}$, $\mathrm{HBeAg}$, anti-HBC and anti-HCV positive) from all laboratories, blood transfusion organizations, hospitals, health centres and district health centres are compulsory since 2004. Moreover, a questionnaire that includes demographic characteristics, risk factors, examination cause and disease status was completed by health staff based on the patient's interview data. Finally, all data were registered in the province health centre database. For the present study, all subjects with positive HBsAg and antiHCV serological markers who registered between 2011 and 2016 in East Azerbaijan province were included.

For estimating the incidence rate, the total population of East Azerbaijan, population of each county and also age-specific population for each year were obtained from the national Iranian census for 2016. The incidence rate for each year was calculated by the number of cases reported in a particular calendar year per 100 ooo total population. The age-specific and also county-specific incidence rate was calculated as follows: (number of new cases) / (person-time at risk). Person-time at risk is calculated as follows: [(number of people at risk at the beginning of the time interval + number of people at risk at the end of the time interval) / 2] $\times$ (number of years in the time interval).

\section{Statistical analysis}

SPSS V25 and Microsoft excel 2013 were used for statistical analysis. The normality of distribution of continuous variables was tested by using the Kolmogorov-Smirnov test. Continuous variables were presented as mean \pm standard deviations (SD) and the categorical variables were presented as frequency (\%). For determining the average annual rate of reduction or increase (AARR), the regression model was used for estimating beta coefficient and P-value. The log incidence rate and time were considered as dependent and independent variables respectively. Then AARR was calculated based on the following formula: AARR $=(1 \text {-antilog beta })^{*} 100$. The sign of beta indicates the direction of the trend. This method was adapted on the basis of information provided in a UNICEF technical note (10).

\section{Results}

Over the 6-year period (2011-2016), 3119 hepatitis cases in East Azerbaijan province were reported to the national notifiable diseases surveillance system; of these, 94.7\% were $\mathrm{HBV}$, $4.9 \%$ were $\mathrm{HCV}$, and $0.4 \%$ were $\mathrm{HBV}$ and HCV co-infection. The mean age of the participants was $39.52 \pm 14.76$ years. The baseline characteristics of participants are shown in Table 1 . The frequency of HBV was higher in females. However, the frequency of $\mathrm{HCV}$ and $\mathrm{HBV}-\mathrm{HCV}$ co-infection was higher in males. As indicated, $89.31 \%$ of the cases were married and $55.47 \%$

\begin{tabular}{|c|c|c|c|c|}
\hline Variable & $\begin{array}{c}\text { Total } \\
(n=3119)\end{array}$ & $\begin{array}{c}\text { HBV } \\
(\mathrm{n}=2957 \\
94.7 \%)\end{array}$ & $\begin{array}{c}\text { HCV } \\
(n=151, \\
4.9 \%)\end{array}$ & $\begin{array}{c}\text { HBV+ } \\
\text { HCV } \\
(\mathrm{n}=11, \\
0.4 \%)\end{array}$ \\
\hline \multicolumn{5}{|l|}{ Sex } \\
\hline Male & $1517(48.6)$ & $1390(47.0)$ & 111 (77.0) & $9(81.8)$ \\
\hline Female & $1602(51.3)$ & $1567(53.0)$ & $33(22.9)$ & $2(18.1)$ \\
\hline \multicolumn{5}{|l|}{ Marital status } \\
\hline Married & $2776(89.3)$ & 2669 (90.6) & $97(63.3)$ & $10(90.9)$ \\
\hline Single & $250(8.0)$ & $210(7.1)$ & $39(26.7)$ & $1(9.0)$ \\
\hline Divorced & $15(0.4)$ & $7(0.3)$ & $8(5.2)$ & - \\
\hline Widow & $65(2.0)$ & $58(1.9)$ & $7(4.5)$ & - \\
\hline \multicolumn{5}{|l|}{ Location } \\
\hline Capital city & $1374(44.5)$ & $1296(43.8)$ & $74(49)$ & $4(36.4)$ \\
\hline Suburban areas & $1712(55.4)$ & $1661(56.2)$ & $77(51)$ & $7(63.6)$ \\
\hline \multicolumn{5}{|l|}{ Risk factors } \\
\hline $\begin{array}{l}\text { Infection in other } \\
\text { family members }\end{array}$ & $644(20.6)$ & $639(24.6)$ & $4(2.6)$ & $1(9.1)$ \\
\hline Blood transfusion & $57(8.1)$ & $51(1.7)$ & $6(4)$ & - \\
\hline Sexual contact & $35(1.1)$ & $11(0.4)$ & $7(4.6)$ & - \\
\hline $\begin{array}{l}\text { Intravenous drug } \\
\text { users }\end{array}$ & $53(1.7)$ & $11(0.4)$ & $27(17.9)$ & $1(0.9)$ \\
\hline Dialysis & $36(1.2)$ & $16(0.5)$ & $20(13.2)$ & - \\
\hline Mother to child & $7(0.2)$ & $7(0.2)$ & - & - \\
\hline Health worker & $11(0.4)$ & $11(0.4)$ & - & - \\
\hline Others & $2250(72.1)$ & $387(13.1)$ & $68(45)$ & $8(72.7)$ \\
\hline Non responders & $40(1.3)$ & $37(1.3)$ & $2(1.3)$ & $1(0.9)$ \\
\hline \multicolumn{5}{|l|}{ Clinical spectrum } \\
\hline Chronic & $2718(87.8)$ & $2580(87.9)$ & $129(86)$ & $10(83.3)$ \\
\hline Carrier & $408(13.1)$ & $385(13.3)$ & $20(13.3)$ & $2(16.6)$ \\
\hline Acute & $108(3.4)$ & $99(3.3)$ & $8(5.3)$ & $1(8.3)$ \\
\hline ND & $269(8.6)$ & $255(8.6)$ & $13(8.6)$ & $1(8.3)$ \\
\hline
\end{tabular}

were living in suburban areas. The frequency of HBV was higher in suburban areas; however, the frequency of HCV was higher in urban areas, and $87.81 \%$ of cases were chronic.

Figure 1 depicts the incidence rate of $\mathrm{HBV}$ and $\mathrm{HCV}$ stratified by year. According to this figure, there was a steady decrease in frequency and incidence rate of HBV between 2011 and 2016. The results of the regression analysis showed that the incidence rate of $\mathrm{HBV}$ decreased significantly $\left(R^{2}=0.89 ; \beta=-0.136, P=0.005\right)$. $\mathrm{HBV}$ incidence rate was reduced by $12.71 \%$ annually from 2011 to $2016($ AARR $=12.71 \%)$. However, the number of $\mathrm{HCV}$ patients increased from 2014 to 2016. According to the regression analysis results, the incidence rate of $\mathrm{HCV}$ increased insignificantly $\left(R^{2}=0.18 ; \beta=0.109, P=0.39\right)$.

Figure 2 presents the frequency and incidence rate of hepatitis by age. The majority of individuals with HBV and HCV infections were 25-44 years old and the lowest frequency was seen in those under 5 years of age. 
Figure 1 The incidence rate of hepatitis $B(\mathrm{HBV})$ and hepatitis $C$ (HCV) by year
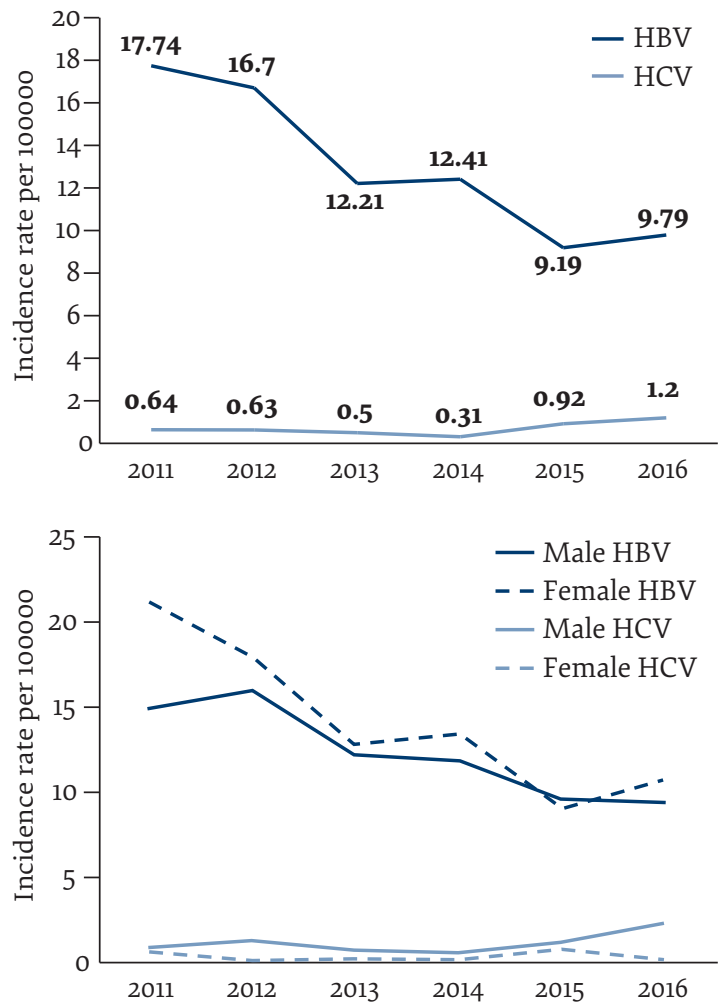

The frequency of HBV and HCV by counties is shown in Figure 3. The highest incidence rate of $\mathrm{HBV}$ was observed in Bonab county (28.33/100 000) followed by Hashtrood (26.54/100 00o) and Malekan (22.99/100 00o). The lowest incidence rate of HBV was observed in Varzagan county (2.03/100 000). In the case of HCV, the highest incidence rate was reported in Mianeh county (1.98/100 000). In Charoimag, Heris, Khodafarin and Varzagan no case of HCV was reported.

\section{Discussion}

In the present study, we aimed to determine the 6-year incidence rate of HBV and HCV in East Azerbaijan province. In total, from 2011 to 2016 there were 3119 hepatitis cases in East Azerbaijan reported to the national notifiable diseases surveillance system. The rate of HBV incidence in East Azerbaijan was similar to the incidence rate of HBV in Hamedan province (2004-2009) (8); however, it is lower than the reported incidence rate in Ilam province (200-2013). Moreover, we showed the downward trend in HBV incidence from 2011 to 2016 [17.74/100 000 (2011) to 10.22/100 000 (2016)], which may be due to the implementation of the vaccination programme in the country from 1993 (11). Previously, a decrease in HBV incidence after initiation of a vaccination programme had been reported in Italy (12). In addition to the vaccination programme, all blood donors were screened for hepatitis infection in the Islamic Republic of Iran from 1996
(13) and high-risk donors were eliminated; therefore, the transmission route was excluded. Furthermore, screening of pregnant women for hepatitis infection decreases the vertical transmission of hepatitis virus (14).

Considering the AARR $=-12.71 \%$, we are expecting that the incidence rate of $\mathrm{HBV}$ will reach 5.00/100 000 in 2020, which is in accordance with the WHO target for 2020 (30\% reduction in HBV incidence compared with the 2015 baseline). The decreasing trend of HBV incidence has also been reported in previous studies; in Hamadan province the decrease in HBV incidence was reported from 2004 to 2009 (19.6 to 7.70) (8). Moreover, in studies conducted among blood donors in the Islamic Republic of Iran, the decline in the frequency of HBV infection has been reported (15-17). However, contrary to these results, Khazaei et al. (2018) showed an increase in HBV incidence from 2008 to 2013 in Ilam province (7). A similar increase was reported in Poland from 2005 to 2013 (18). The differences between the results of various studies may be due to the differences in region and also the time of the studies.

Figure 2 The frequency and incidence of hepatitis B (HBV) and hepatitis $\mathrm{C}$ (HCV) by age group
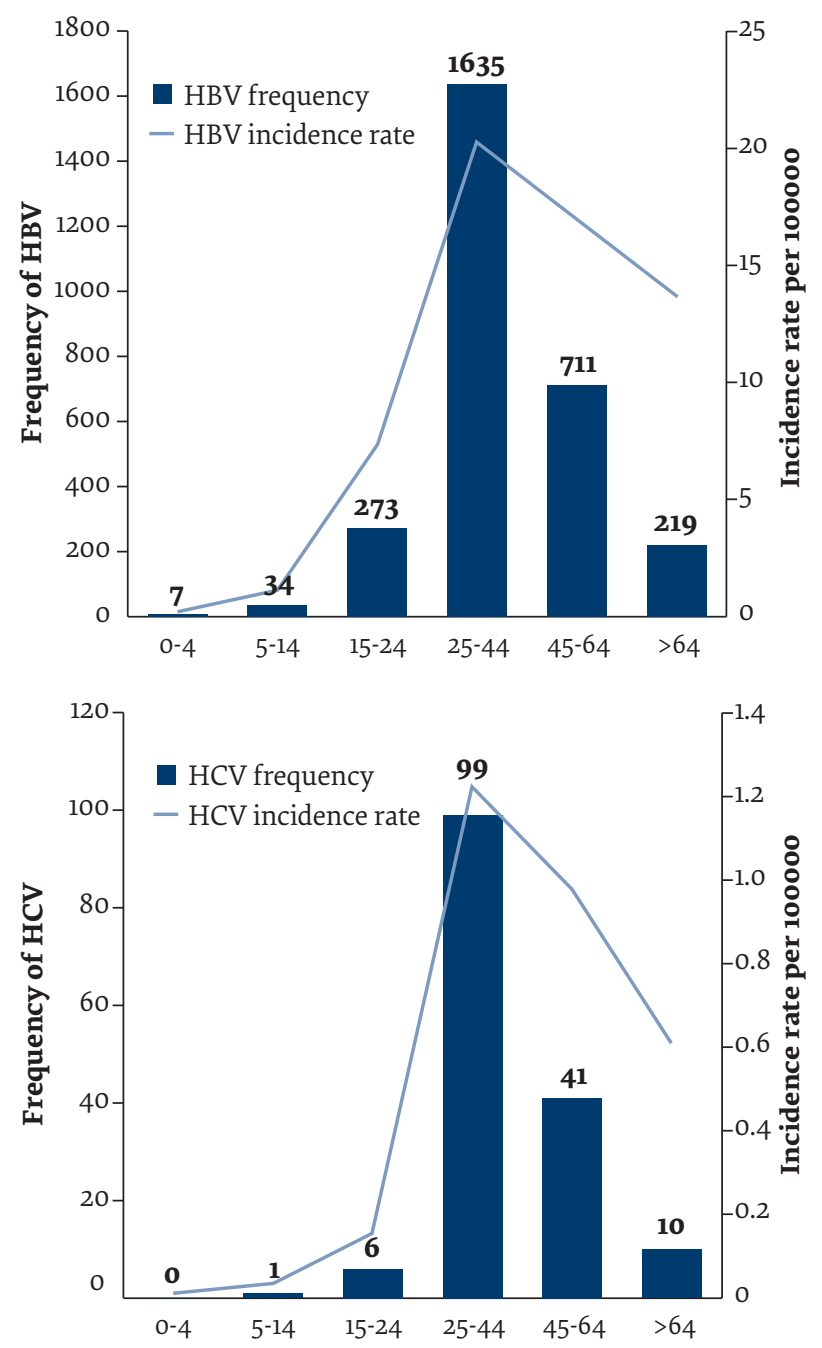


\section{Figure 3 The incidence of hepatitis B (HBV) and hepatitis C (HCV) by county}

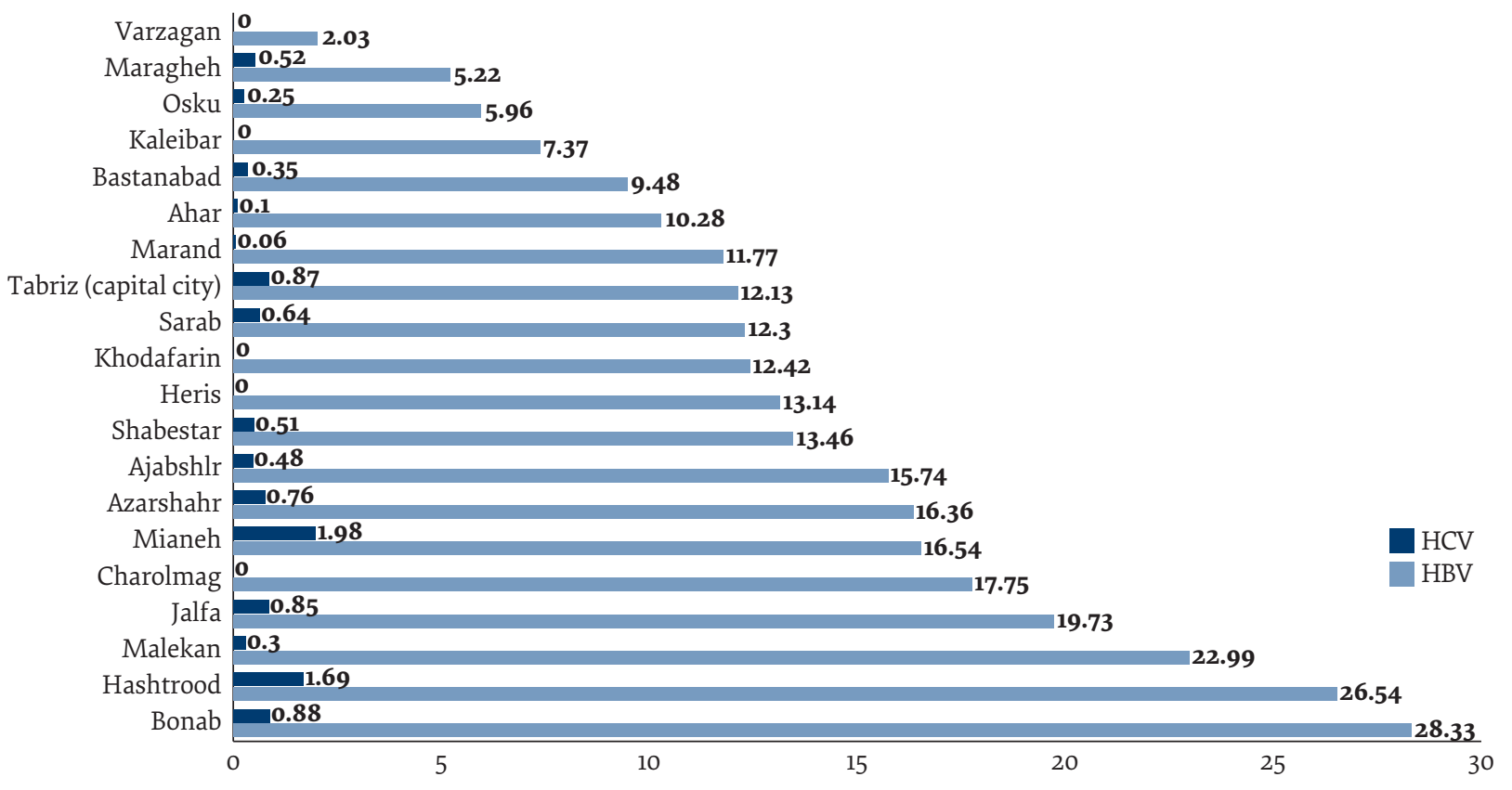

According to the results, the incidence rate of $\mathrm{HCV}$ had a decreasing trend from 2011 to 2013. However, the number of HCV patients increased from 2014 to 2016. A similar increase in HCV incidence has been reported in other studies in the Islamic Republic of Iran. In a study in Ilam province, the increasing trend in $\mathrm{HCV}$ incidence was reported from 2008 to 2013 (7). Moreover, Merat et al. reported an increase in HCV seroprevalence in the country (19). All Iranian HCV patients were treated using SOVODAK - a single pill containing Sofosbuvir and Daclatasvir - which has been shown to provide a $98 \%$ sustained virologic response (SVR) in HCV patients (20). Therefore, it is expected in this case that the WHO target for 2020 will be reached.

Unlike previous studies conducted in the Islamic Republic of Iran $(7,8)$, the results of this study showed the higher incidence rate of HBV in females. Moreover, Merat et al. in a study in three Iranian provinces showed that there are no sex differences in the HBV prevalence rate. The differences between the results of different studies may be due to the compulsory screening of hepatitis in pregnant women. On the other hand, in line with the results of the previous study (19), the incidence rate of HCV was higher in males than females. This can be attributed to the higher frequency of injecting drug use among males.

In accordance with the findings of earlier studies conducted in the Islamic Republic of Iran $(7,8)$, the peak age for both HBV and HCV incidence was 25-44 years old. As a result of the initiation of the HBV vaccination programme in 1993, most of the under 25-year-old population was immunized for hepatitis B in 2016. Thus, as expected the incidence rate in these groups is very low. However, most of the people in the 25-44 years old age group were not immunized. On the other hand, people in this age group are of reproductive age and the frequency of marriage and consequently sexual contact between couples is high, which may affect hepatitis transmission. Moreover, the pregnancy rate in this age group is high. Therefore, the higher incidence rate in this age group could partly be attributed to implementing compulsory screening programmes of $\mathrm{HBV}$ in pregnant women.

More than $70 \%$ of participants in the present study did not define the exact risk factor for hepatitis transmission. In a study conducted by Centers for Diseases control and Prevention (CDC), more than $45 \%$ of cases did not report any known exposure risk (21). Considering that the main means of hepatitis transmissions are illegal (such as drug injection), most of the patients are unwilling to indicate the main route of transmission. In the present study about $20 \%$ of subjects had a positive HBV or HCV case in their household. The higher prevalence of hepatitis in family members, especially immediate relatives, had been reported in previous studies $(7,22,23)$ that may be due to the horizontal mode of transmission and also the exposure to the same risk factors in the household (7).

According to the results, the prevalence of $\mathrm{HBV}$ was higher in certain counties including Bonab, Hashtrood and Malekan, which may be due to using unsterilized equipment for activities such as dental procedures, acupuncture, shaving, and hair cutting.

\section{Limitations}

In the present study we used the data of the national notifiable diseases surveillance system in East Azerbaijan. The limitations of this system, including underreporting due to the passive model of surveillance model, also apply to the present study. Moreover, the data for HCV 
were reported based on HCV anti-bodies in the present study that may prove to be false positive results. In addition, due to the asymptomatic nature of hepatitis, most patients were diagnosed accidentally. Therefore, the actual incidence of hepatitis may be higher. However, in the present study, we aimed to elucidate the trend of incidence over 6 years and it appears that this system could provide a valuable means to achieve this aim.

\section{Conclusion}

The results of the present study showed the downward trend of HBV in East Azerbaijan, which is in accordance with the WHO target for 2020. Moreover, the low incidence of HBsAg among people aged under 25 years demonstrates the effectiveness of national vaccination programmes for neonates in reducing HBV infection. However, the incidence of HCV has insignificantly increased in recent years. Thus, considering the availability of effective treatment regimens for hepatitis $C$, policy-makers should focus on $\mathrm{HCV}$ screening and diagnosis in addition to implementing education and prevention programmes.

Funding: East Azerbaijan Provincial Health Center and Liver and Gastrointestinal Diseases Research Center, Tabriz University of Medical Sciences, Islamic Republic of Iran.

Competing interests: None declared.

\section{Estimation du taux d'incidence de l'hépatite B et C en Azerbaïdjan oriental (République islamique d'Iran)}

\section{Résumé}

Contexte : L'Organisation mondiale de la Santé (OMS) a pour objectif de réduire de 30 \% l'incidence de l'hépatite B (VHB) et de l'hépatite C (VHC) à l'horizon 2020. Pour y parvenir, il est important de disposer d'informations actualisées sur l'évolution du taux d'incidence de l'hépatite. Cela dit, les données actualisées émanant de la province d'Azerbaïdjan oriental en République islamique d'Iran font défaut.

Objectifs : La présente étude avait pour objectif d'estimer le taux d'incidence du VHB et du VHC de 2011 à 2016 en Azerbaïdjan oriental (République islamique d'Iran).

Méthodes : Des données sur l'hépatite et des données populationnelles ont été obtenues respectivement à partir du système national de surveillance des maladies à déclaration obligatoire et du recensement national iranien de 2016. Afin de déterminer le pourcentage de variation du taux d'incidence par rapport à la base de comparaison, on a calculé le taux de réduction annuel moyen. Pour ce faire, le modèle de régression linéaire a été utilisé pour estimer le coefficient bêta. Le logiciel SPSS V25 a été utilisé pour l'analyse statistique.

Résultats : Sur la période de six ans, 3119 cas d'hépatite dans la province d'Azerbaïdjan oriental ont été signalés, dont $94,7 \%$ étaient des cas d'hépatite B. La majorité des personnes touchées étaient âgées de 25 à 44 ans. L'incidence du VHB a été réduite de 12,71\% par an entre 2011 et 2016. En revanche, le nombre de patients infectées par le VHC a augmenté entre 2014 et 2016 et le taux d'incidence du virus a très légèrement baissé $(\beta=0,109, p=0,39)$.

Conclusion : On observe une tendance à la baisse marquée concernant le VHB en Azerbaïdjan oriental $\mathrm{du}$ fait des programmes de vaccination de masse. Dans le cas du VHC, en envisageant la disponibilité de protocoles thérapeutiques efficaces ainsi que de programmes d'éducation et de prévention, les responsables de l'élaboration des politiques devraient privilégier surtout le dépistage et le diagnostic du VHC, en particulier dans le groupe d'âge 25-44 ans.

$$
\text { تقدير معدل الإصابة بالتهاب الكمد B م التهاب حسين صومي، سيمين خياط زاده، محمد نعلنبدي، شهناز نقاشي، زينب نيكني أذربيجان الشرقية، جمهورية إيران الإسلامية }
$$

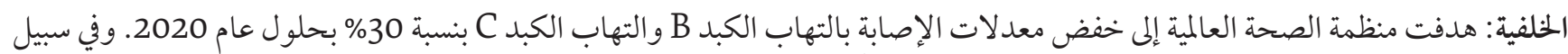

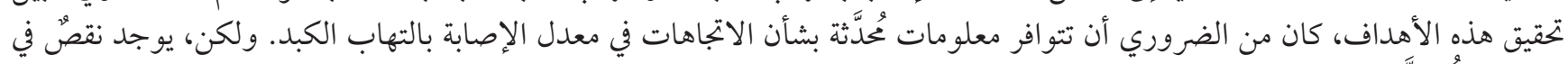

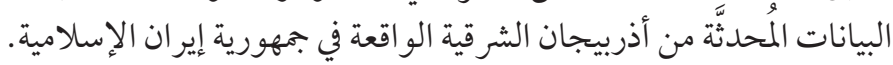

الأهداف: هدفت هذه الدراسة إلى تقدير معدلات الإصابة بالتهاب الكبد B والتهاب الكبد C في الفترة بين عامي 2011 و2016 في أذربيجان

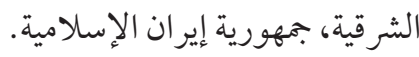

طرق البحث: تم الحصول على البيانات الخاصة بالتهاب الكبد وتلك الخاصة بالسكان من النظام الوطني لترصد الأمراض التي يجب التب التبليخ بها،

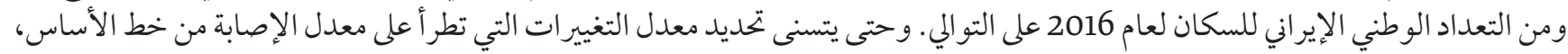


حُسب متوسط الانخفاض السنوي في معدل الإصابة. واستُخدم لهذا الغرض نموذج الانحدار الخطي لتقدير مُعامل البيتا. واسْتُخدمت برمجية SPSS V25

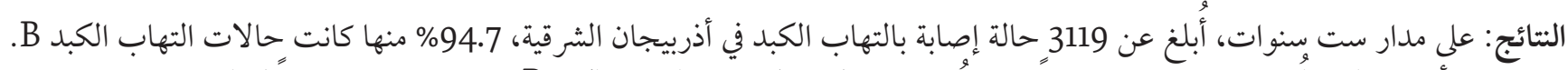

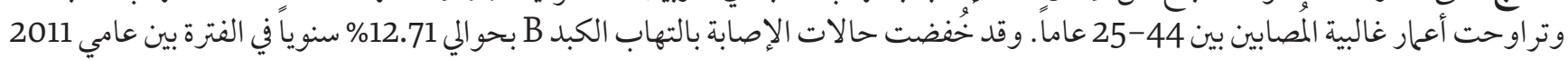

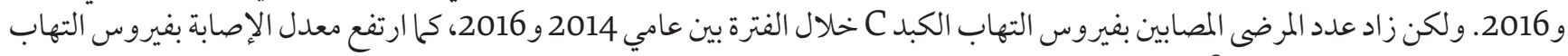
الكبد C بنسبة كبيرة (2016. ول0.

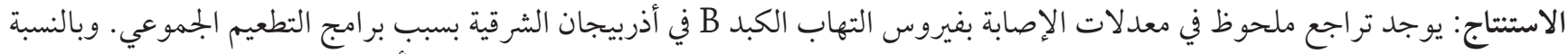

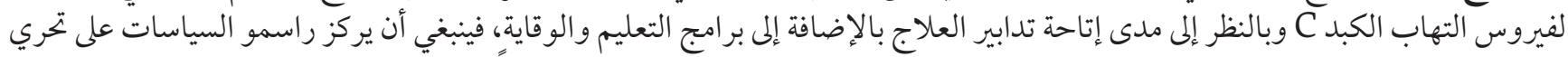

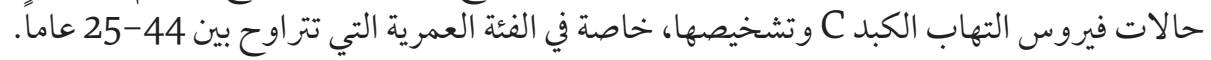

\section{References}

1. Santos DCMd, Souto FJD, Santos DRLd, Vitral CL, Gaspar AMC. Seroepidemiological markers of enterically transmitted viral hepatitis A and E in individuals living in a community located in the North Area of Rio de Janeiro, RJ, Brazil. Mem Inst Oswaldo Cruz. 2002;97(5):637-40.

2. World Health Organization Regional Office for Africa (WHO/AFRO). Hepatitis. Brazzaville: WHO/AFRO; 2019 (https://www. afro.who.int/health-topics/hepatitis, accessed 29 August 2019).

3. World Health Organization. Global hepatitis report 2017. Geneva: World Health Organization; 2017.

4. Fikri M. Eliminating hepatitis from the Eastern Mediterranean Region. East Mediterr Health J. 2017;23(7):459.

5. André F. Hepatitis B epidemiology in Asia, the Middle East and Africa. Vaccine. 2000;18:S20-S2.

6. Salehi-Vaziri M, Sadeghi F, Hashiani AA, Fesharaki MG, Alavian SM. Hepatitis B virus infection in the general population of Iran: an updated systematic review and meta-analysis. Hepat Mon. 2016;16(4).

7. Khazaei S, Karami M, Ayubi E, Mohammadbeigi A, Hasanbeigi A, Mansori K, et al. Trends in epidemiology of hepatitis B and C infections in Ilam Province: National notifiable diseases surveillance system data. Caspian J Intern Med. 2018;9(1):16.

8. Poorolajal J, Mirzaei M, Bathaei SJ, Majzoobi MM. Hepatitis B and C infections in hamadan province during 2004-2009. J Res Health Sci. 2011;1(1):51-7.

9. Bayat-Makou J, Shahnazi A, Koushavar H. Prevalent infections in north-west region of Tabriz. Med J Tabriz Univ Med Sci. 2003;59(30).

10. UNICEF. Technical note "How to calculate Average Annual Rate of Reduction (AARR) of Underweight Prevalence", Statistics and Monitoring Section/Division of Policy and Practice/UNICEF, Drafted, 2017; (http://www.childinfo.org/files/Technical_Note_ AARR).

11. Alavian S-M. Ministry of Health in Iran is serious about controlling hepatitis B. Hepat Mon. 2007;7(1):3-5.

12. Zanetti AR, Van Damme P, Shouval D. The global impact of vaccination against hepatitis B: a historical overview. Vaccine. 2008;26(49):6266-73.

13. Alavian SM, Adibi P, Zali MR. Hepatitis C virus in Iran: Epidemiology of an emerging infection. Arch Iranian Med. 2005;8(2), 84-90.

14. Hashemi-Shahri SM, Sharifi-Mood B, Khalili M. Review of the prevention of the hepatitis B virus infection transmission from mother to child during pregnancy. Int J Infect. 2015;2(3).

15. Hosseien K, SeyyedMohammad M, Mohsen A, Hassan A, Bashir H, Farshid A, et al. Trends in seroprevalence of hepatitis B, hepatitis C, HIV, and syphilis infections in Iranian blood donors from 2003 to 2005. Hepat Mon. 2009;2009(1):24-8.

16. Mohammadali F, Pourfathollah AA. Changes in frequency of HBV, HCV, HIV and syphilis infections among blood donors in Tehran province 2005-2011. Arch Iran Med. 2014;17(9):613-20. doi:0141709/aim.006. PubMed:25204477.

17. Keshvari M, Sharafi H, Alavian SM, Mehrabadi H, Zolfaghari S. Prevalence and trends of transfusion-transmitted infections among blood donors in Tehran, Iran from 2008 to 2013. Transfus Apher Sci. 2015;53(1):38-47. doi:10.1016/j.transci.2015.03.003. PubMed:25892591.

18. Stawinska-Witoszynska B, Zysnarska M, Krzywinska-Wiewiorowska M, Wojtyla-Buciorab P, Krzyzaniak A, Wieckowska B. Trends in the incidence rates of chronic hepatitis B in Poland in the years 2005-2013. Hepat Mon. 2016;16(8):e32692. doi:10.5812/ hepatmon.32692. PubMed:27799960.

19. Merat S, Rezvan H, Nouraie M, Jafari E, Abolghasemi H, Radmard AR, et al. Seroprevalence of hepatitis C virus: the first population-based study from Iran. Int J Infect Dis. 2010;14:e113-e6.

20. Merat S, Sharifi AH, Haj-Sheykholeslami A, Poustchi H, Fattahi B, Nateghi-Baygi A, et al. The efficacy of 12 weeks of Sofosbuvir, Daclatasvir, and Ribavirin in treating hepatitis C patients with cirrhosis, genotypes 1 and 3. Hepat Mon. $2017 ; 17(1): e 44564$. doi:10.5812/hepatmon.44564. 
21. Smith BD, Morgan RL, Beckett GA, Falck-Ytter Y, Holtzman D, Teo C-G, et al. Recommendations for the identification of chronic hepatitis C virus infection among persons born during 1945-1965. Morbidity and Mortality Weekly Report: Recommendations and Reports. 2012;61(4):1-32.

22. Akhtar S, Moatter T. Intra-household clustering of hepatitis C virus infection in Karachi, Pakistan. Trans R Soc Trop Med Hyg. 2004;98(9):535-9.

23. Irfan A, Arfeen S. Hepatitis C virus infection in spouses. Pak J Med Res. 2004;43(3):113-6. 